\title{
United States - Use of Zeroing in Anti- Dumping Measures Involving Products from Korea: It's déjà vu all over again
}

\author{
THOMAS J. PRUSA* \\ Rutgers University and NBER \\ LUCA RUBINI** \\ University of Birmingham
}

\begin{abstract}
This paper analyzes the dispute between Korea and the United States regarding the method of calculating anti-dumping duties. The case mirrors other recent WTO disputes involving zeroing. Even though it ceased zeroing in original investigations in December 2006, the United States implemented the policy change only prospectively. As a result, the margins applied to the products in this dispute remained unchanged because they had been calculated prior to the policy change. The United States did not contest Korea's claims. The Panel confirmed that zeroing was used and, following the long line of Panel and Appellate Body rulings, found the practice inconsistent with the Anti-Dumping Agreement. After the Panel Report was adopted, the United States recalculated the margins without zeroing. It, however, refused to refund unliquidated cash deposits that were based on zeroing, highlighting the United States's continued lukewarm compliance with WTO rulings on zeroing. This dispute offers an opportunity to ponder on weaknesses of the WTO Dispute Settlement and the ability of one Member to take advantage of it. Since the facts and their legal assessment were undisputed, why was litigation necessary? Can compliance with WTO law be improved with broader findings and more incisive remedies?
\end{abstract}

[I]nternational legal arrangements have relatively more in common with the law of primitive societies studied by anthropologists, in which litigation is still emerging as a rather tenuous alternative to dispute resolution by force. International litigation is an institution of indeterminate character. It is not an inevitable response to legal disputes, nor does it supply a conclusive outcome. ${ }^{1}$

*Email: prusa@econ.rutgers.edu.

**Email: 1.rubini@bham.ac.uk.

The views expressed in this paper are those of the authors and all omissions and errors are also of the authors. We would like to thank Dukgeun Ahn, Sungioon Cho, Jim Durling, Gary Horlick, Rob Howse and Seong-Joong Kim for helpful discussions.

1 Robert E. Hudec (1987), "“Transcending the Ostensible": Some Reflections on the Nature of Litigation Between Governments', 72 Minnesota Law Review, 211, 212-213. 


\section{Introduction}

United States-Use of Zeroing in Anti-Dumping Measures Involving Products from Korea ${ }^{2}$ is another WTO dispute involving the United States's practice of zeroing negative dumping margins in calculating overall weightedaverage margins of dumping. ${ }^{3}$ In this dispute, the measures at issue are the final determinations, amended final determinations, anti-dumping duty orders, and amended anti-dumping duty orders imposed by the United States in relation to imports of the three products: stainless-steel plate in coils (SSPC), stainless-steel sheet and strip in coils (SSSSC), and diamond sawblades (DS). ${ }^{4}$

At first blush, the dispute is seemingly superfluous because the United States [US] ceased zeroing in original investigations [OI] almost three years before Korea requested consultations. ${ }^{5}$ Why would Korea complain about zeroing when the US had already stopped zeroing? The conflict hinges on the particular way the US changed its domestic law to eliminate zeroing. Although the US stopped zeroing in OI in December 2006, it did so only prospectively; that is, the US's new rules only apply to margin calculations performed after the implementation date. ${ }^{6}$ According to the US, all anti-dumping [AD] margins computed prior to the date of its policy change, including the margins in this dispute, were unaffected by the WTO's prior determinations.

US-Zeroing (Korea) has many parallels with US-PET Bags (Thailand). ${ }^{7}$ While the current dispute is somewhat more complicated than US - PET Bags (Thailand),

2 United States - Use of Zeroing in Anti-Dumping Measures Involving Products from Korea, WT/ DS402/R, adopted 24 February 2011 (hereafter, US-Zeroing (Korea)).

3 Over the past decade, the WTO Appellate Body has heard at least 20 disputes involving various types of zeroing and each time has found that the practice violates the WTO Anti-Dumping Agreement. All but two of the cases have involved the United States as respondent. For a review of WTO cases involving zeroing, see Chad P. Bown and Thomas J. Prusa (2011), 'US Anti-Dumping: Much Ado about Zeroing', in William J. Martin and Aaditya Mattoo (eds.), Unfinished Business? The WTO's Doha Agenda, London: CEPR and the World Bank, pp. 355-392.

4 US-Zeroing (Korea), para. 2.1.

5 'Anti-Dumping Proceedings: Calculation of the Weighted-Average Dumping Margin During an Anti-Dumping Investigation, Final Modification', Federal Register, 71: 248 (27 December 2006), pp. 77722-77725 (hereafter, '2006 Modification'). The effective date of this final modification was 16 January 2007.

6 To be more precise, the 2006 Modification reads: 'The Department will apply this final modification in all current and future antidumping investigations as of the effective date.' All three cases in this dispute had their OI margins calculated prior to this date and hence were not subject to the new rules.

7 Panel Report, United States-Anti-Dumping Measures on Polyethylene Retail Carrier Bags from Thailand, WT/DS383/R, adopted 18 February 2010, DSR 2010:IV, 1841 (hereafter, US-PET Bags (Thailand)). For an analysis of that dispute, see Thomas J. Prusa and Edwin Vermulst (2012), 'United States - Anti-Dumping Measures on Polyethylene Retail Carrier Bags from Thailand: A Cat in the Bag', 11:2 World Trade Review, 257-271. 
Table 1. Key dates in US proceedings

\begin{tabular}{llll}
\hline \hline & \multicolumn{3}{c}{ Product } \\
\cline { 2 - 4 } & \multicolumn{1}{c}{ SSPC } & SSSSC & \multicolumn{1}{c}{ DS } \\
\hline Petition Initiated & 27 April 1998 & 13 July 1998 & 21 June 2005 \\
$\begin{array}{l}\text { Final OI AD Duty } \\
\text { (W-W method) }\end{array}$ & $\begin{array}{l}\text { 31 March 1999 } \\
\text { (amended 28 August 2001) }\end{array}$ & $\begin{array}{c}\text { 8 June 1999 } \\
\text { (amended 28 } \\
\text { August 2001) }\end{array}$ & $\begin{array}{l}\text { 22 May 2006 } \\
\text { (amended 24 March 2010) }\end{array}$ \\
Final Injury & 12 May 1999 & 28 July 1999 & $\begin{array}{c}\text { 11 July 2006 (remanded } \\
\text { 13 January 2009) }\end{array}$ \\
AD Order & $\begin{array}{c}\text { 21 May 1999 (amended } \\
\text { 11 March 2003, 2 April 2003, } \\
\text { and 24 April 2003) }\end{array}$ & 27 July 1999 & 4 November 2009 \\
& & & \\
\hline \hline
\end{tabular}

the raison d'être for both disputes is identical ${ }^{8}$ - the US Department of Commerce [USDOC] will calculate non-zeroed margins for preexisting cases only after an adverse finding for each particular case. In both US-Zeroing (Korea) and US-PET Bags (Thailand), all evidence indicates that the US perceived it had no chance to prevail at the WTO Dispute Settlement Body [DSB]. In its prior decisions, the WTO Appellate Body $[\mathrm{AB}]$ unfailingly had found zeroing to be inconsistent with the WTO Anti-Dumping Agreement [ADA]. ${ }^{9}$ The US did not contest the claims in either US-Zeroing (Korea) or US-PET Bags (Thailand). In fact, the US acknowledged it had used zeroing when calculating dumping margins in both disputes. Yet, in both disputes the US refused to recalculate the margins upon receipt of the consultation request. As best we can tell, US-Zeroing (Korea) and US-PET Bags (Thailand) were both legal formalities required by USDOC's narrow implementation of WTO rules.

The timing of events highlights the basis for the dispute. As seen in Table 1, the USDOC made final AD margin calculations for all three cases prior to the policy change. In SSPC and SSSSC, the order was in effect long before the USDOC policy change; however, due to legal challenges involving the injury determination, the DS AD order went into effect after the policy change (but, as noted, the USDOC had calculated the OI AD margin before the December 2006 policy change).

In this dispute, Korea challenged the US's continued use of zeroing. On 24 November 2009, Korea requested consultations with the US (Table 2). Consultations were held in December 2009 and February 2010, but failed to resolve the dispute. Korea requested the establishment of a Panel in April 2010.

8 Two issues make this dispute somewhat more complicated. First, unlike US-PET Bags (Thailand) there was not a pre-dispute agreement as to how the Panel's decision would be implemented. Second, this dispute involves three cases rather than just a single claim.

9 Bown and Prusa, 'US Anti-Dumping', Table 14.2, supra at note 3. 
Table 2. Key dates in WTO dispute

\begin{tabular}{|c|c|}
\hline Event & Date \\
\hline Korea requests consultations & 24 November 2009 \\
\hline $\begin{array}{l}\text { US and Korea fail to resolve dispute } \\
\text { in consultations }\end{array}$ & December 2009 to February 2010 \\
\hline Korea requests WTO Panel & 08 April 2010 \\
\hline Final Panel Report circulated & 18 January 2011 \\
\hline Final Panel Report adopted & 24 February 2011 \\
\hline $\begin{array}{l}\text { 'Reasonable period of time' for implementation } \\
\text { established }\end{array}$ & 17 June 2011 \\
\hline New AD duties implemented & $\begin{array}{l}\text { October } 2011 \text { and } \\
\text { November } 2011\end{array}$ \\
\hline $\begin{array}{l}\text { US refuses to recalculate margins for unliquidated } \\
\text { cash deposits }\end{array}$ & February 2012 \\
\hline
\end{tabular}

The final Panel Report was circulated in January 2011 and adopted by the DSB in February 2011. In March 2011, the US announced it intended to implement the DSB's recommendations. Korea and the US were able to agree on the 'reasonable period of time' for implementation by July 2011 . The US recalculated the margins on DS in October 2011 and on SSPC and SSSSC in November 2011. On 8 December 2011, the US reported to the DSB that it had 'fully implemented' the DSB's recommendations and rulings. While not within the scope of the investigation, Korea requested that the US refund unliquidated cash deposits based on the zeroed margins. To date, the US has refused to do so.

Given that (i) the dispute covers extremely well-trodden ground, ${ }^{10}$ (ii) neither party challenged the Panel to push the envelope on zeroing, and (iii) the Panel's reasoning simply restated previous $\mathrm{AB}$ and Panel opinions, we find ourselves with little to say about zeroing beyond what has been previously stated. Instead,

10 Legal and economic summaries of previous zeroing disputes include Merit E. Janow and Robert W. Staiger (2003), 'European Communities - Anti-Dumping Duties on Imports of Cotton-Type Bed Linen from India', in Henrik Horn and Petros C. Mavroidis (eds.), The WTO Case Law of 2001, Cambridge: Cambridge University Press; Gene M. Grossman and Alan O. Sykes (2006), 'European Communities - Anti-Dumping Duties on Imports of Cotton-Type Bed Linen from India: Recourse to Article 21.5 of the DSU by India', in Henrik Horn and Petros C. Mavroidis (eds.), The WTO Case Law of 2003, Cambridge: Cambridge University Press; Chad P. Bown and Alan O. Sykes (2008), 'The Zeroing Issue: A Critical Analysis of Softwood V', 7:1 World Trade Review, 121-142; Thomas J. Prusa and Edwin Vermulst (2009), 'A One-Two Punch on Zeroing: US-Zeroing (EC) and US -Zeroing (Japan)', 8:1 World Trade Review, 187-241; Meredith Crowley and Robert Howse (2010), 'US-Stainless Steel (Mexico)', 9:1 World Trade Review, 117-150; Bernard Hoekman and Jasper Wauters (2011), 'US Compliance with WTO Rulings on Zeroing in Anti-Dumping', 10:1 World Trade Review, 5-43; Thomas J. Prusa and Edwin Vermulst (2011), 'United States - Continued Existence and Application of Zeroing Methodology: The End of Zeroing?', 10:1 World Trade Review, 45-61; Prusa and Vermulst, 'United States - Anti-Dumping Measures on Polyethylene Retail Carrier Bags from Thailand', supra at note 7. 
our commentary will focus on three subordinate issues. First, how should the Panels handle undisputed claims? What is the real issue with such claims? Second, what does the US's insistence on adverse finding before it will recalculate margins imply for the WTO DSU, its remedies, and other member countries? Third, is it reasonable to expect the US to refund unliquidated cash deposits that were based on OI margins calculated with zeroing?

In the next section, we review the claims and summarize the Panel's findings. Next, we discuss how the US implemented the Panel's recommendations. We then offer commentary on the ancillary issues associated with this dispute.

\section{Claims and Panel findings}

Zeroing refers to the practice of replacing the actual amounts of dumping that yield negative dumping margins with a value of zero prior to the final calculation of a weighted-average margin of dumping for the product under investigation with respect to the exporters under investigation. Zeroing drops transactions that have negative margins from the numerator and hence increases overall dumping margins and the resulting size of the applied anti-dumping duty. ${ }^{11}$ While there are several forms of zeroing, ${ }^{12}$ the present case concerned the relatively simple form of model zeroing under the weighted-average-to-weighted-average comparison method in original investigations.

Korea claimed that the USDOC had used the model-zeroing methodology to determine the final dumping margins for individually investigated Korean exporters whose margins of dumping were not based on total facts available, in violation of Article 2.4.2 of the ADA. ${ }^{13}$ In particular, Korea claimed that the USDOC (i) identified different 'models', i.e., types, of products based on the most relevant product characteristics; (ii) calculated weighted-average prices in the US and weighted-average normal values in the comparison market on a model-specific basis for the entire period of investigation; (iii) compared the weighted-average normal value of each model to the weighted-average US price for that same model; (iv) calculated the dumping margin for an exporter by summing up the amount of dumping for each model and then dividing it by the aggregated US price for all models; and (v) set to zero all negative margins on individual models before summing the total amount of dumping for all models. ${ }^{14}$

The US did not contest Korea's claims. It acknowledged the accuracy of Korea's description of the USDOC's use of zeroing and recognized that in US-Softwood

11 Prusa and Vermulst, 'A One-Two Punch on Zeroing', supra at note 10, provide an extended discussion of how zeroing affects the calculated margin.

12 See, e.g., ibid.; Edwin Vermulst and Daniel Ikenson (2007), 'Zeroing under the WTO Anti-Dumping Agreement: Where Do We Stand?', 2:6 Global Trade and Customs Journal, 231-242.

13 US-Zeroing (Korea), paras. 2.2-2.7.

14 Ibid., para. 7.3. 
Lumber $V^{15}$ the $\mathrm{AB}$ found that the use of zeroing with respect to the averageto-average comparison methodology in investigations was inconsistent with Article 2.4.2 by interpreting the terms 'margins of dumping' and 'all comparable export transactions' in an integrated manner. The US also acknowledged that reasoning was equally applicable in the present case. ${ }^{16}$

The Panel considered that the issues raised in the present case were very similar to those addressed by the Panels in US-Shrimp (Ecuador), ${ }^{17}$ US-Shrimp (Thailand), ${ }^{18}$ and US-PET Bags (Thailand) and agreed with the approach adopted by those Panels. ${ }^{19}$

The Panel then first considered its role under Article 11 of the DSU, in light of the fact that the US did not contest Korea's claim. Article 11 of the DSU describes the role of Panels in DSB proceedings requiring that the 'Panel should make an objective assessment of the matter before it, including an objective assessment of the facts of the case and the applicability of and conformity with the relevant covered agreements and make such other findings as will assist the DSB in making the recommendations or in giving the rulings provided for in the covered agreements'. Notwithstanding the US's decision not to contest Korea's claim, the Panel explained that it was bound by Article 11 of the DSU to make 'its own objective assessment of the matter before it, including an objective assessment of the facts and the applicability of and conformity with the covered agreements as required by Article 11 of the DSU'. ${ }^{20}$

The Panel consequently adopted the approach followed by the Panel in USShrimp (Ecuador). ${ }^{21}$ The Panel thus reasoned that, in the absence of effective refutation by the defending party, it is still required for the complaining party to present a prima facie case. The Panel could thus only rule in favor of Korea if it was satisfied that Korea had made a prima facie case regarding its zeroing claim. ${ }^{22}$

In order to establish that the USDOC zeroed in the present case, Korea referred to a computer program used by the USDOC to calculate dumping margins. The Panel found, in that respect, that the computer program indeed indicated the use of zeroing by the USDOC. The Panel furthermore repeated that the US had

15 Appellate Body Report, United States - Final Dumping Determination on Softwood Lumber from Canada, WT/DS264/AB/R, adopted 31 August 2004, DSR 2004:V, 1875 (hereafter, US-Softwood Lumber V).

16 US-Zeroing (Korea), para. 3.2.

17 Panel Report, United States-Anti-Dumping Measure on Shrimp from Ecuador, WT/DS335/R, adopted on 20 February 2007, DSR 2007:II, 425 (hereafter, US-Shrimp (Ecuador)).

18 Panel Report, United States - Measures Relating to Shrimp from Thailand, WT/DS343/R, adopted 1 August 2008, as modified by Appellate Body Report WT/DS343/AB/R, WT/DS345/AB/R, DSR 2008: VII, 2539 (hereafter, US-Shrimp (Thailand)).

19 US-Zeroing (Korea), para. 7.17.

20 Ibid., para. 7.8 .

21 US-Shrimp (Ecuador), paras. 7.7-7.11.

22 US-Zeroing (Korea), para. 7.19. 
acknowledged the accuracy of Korea's description of the USDOC's use of zeroing. The Panel therefore concluded that it was satisfied that Korea had demonstrated that the USDOC zeroed in the measure at issue. ${ }^{23}$

The Panel then verified whether Korea had established that the methodology used by the USDOC was indeed the same in all legally relevant aspects as the methodology reviewed by the Appellate Body in US-Softwood Lumber V. Korea relied on the description of the methodology used in the USDOC's notice of preliminary determination of sales at less than fair value, as well as the computer program used to determine the dumping margins. According to the Panel, this was sufficient evidence to establish that the USDOC performed the actions as claimed by Korea in points (i) to (v) above. ${ }^{24}$

The Panel considered that the absence of any denial by the US and the abovementioned evidence established that Korea had demonstrated that the methodology applied by the USDOC in calculating the margins of dumping that were not based on total facts available was the same as the methodology that the Appellate Body in US-Softwood Lumber V had found to be inconsistent with Article 2.4.2 of the ADA. ${ }^{25}$

Finally, the Panel verified whether Korea had established that the methodology applied by the USDOC was inconsistent with Article 2.4.2 of the ADA. The Panel considered, in that respect, that while it was not strictly speaking bound by the reasoning in prior Panel or AB Reports, ${ }^{26}$ adopted Reports do create 'legitimate expectations' among WTO members and found that following the $\mathrm{AB}$ conclusions in earlier Reports would not only be appropriate but would also be what would be expected, especially where the issues are the same. ${ }^{27}$

The Panel referred to the Panel Report in US-Shrimp (Ecuador) with regard to the AB's reasoning in US-Softwood Lumber $V$ concerning the compatibility of zeroing with Article 2.4.2 of the ADA. ${ }^{28}$ The AB in US-Softwood Lumber $V$ had found that it was clear from the texts of Article VI:1 of the GATT 1994 and Article 2.1 of the ADA that dumping is assessed in relation to the product as a whole as defined by an investigating authority and cannot be found to exist only for a type, model, or category of that product. The AB in US-Softwood Lumber V on that basis concluded that the treatment of comparisons for which the weighted-average normal value is less than the weighted-average export price as 'non-dumped' comparisons was not in accordance with the requirements of Article 2.4.2 of the ADA.

23 Ibid., para. 7.22 .

24 Ibid., paras. 7.23-7.26.

25 Ibid., para. 7.27.

26 Since 'there is not a system of precedent within the WTO dispute settlement system', US-Zeroing (Korea), para. 7.31 .

27 Ibid., para. 7.30 .

28 US-Shrimp (Ecuador), paras. 7.38-7.39. 
The Panel also noted that the Panel in US-Shrimp (Ecuador) found that there was a consistent line of $\mathrm{AB}$ Reports that holds that zeroing in the context of the weighted-average-to-average methodology in original investigations was inconsistent with Article 2.4.2 of the Anti-Dumping Agreement. ${ }^{29}$

The Panel therefore concluded that given that the issues raised in the present case were identical in all material respects to those addressed by the AB in US-Softwood Lumber $V$, Korea had established a prima facie case that the use of zeroing by the USDOC was inconsistent with Article 2.4.2 of the ADA, because the USDOC did not calculate those dumping margins on the basis of the product as a whole, taking into account all comparable export transactions. ${ }^{30}$

\section{US implementation}

With the adverse WTO Panel ruling, the USDOC proceeded to recalculate the AD margins. On 17 June 2011, Korea and the US informed the WTO that they had mutually agreed that the US would comply with the Panel's recommendations and rulings no later than 1 December 2011. ${ }^{31}$ On 19 December 2011, the US reported that it had fully implemented the Panel's recommendations and rulings within the reasonable period of time agreed by the parties. ${ }^{32}$

The table below (Table 3) summarizes the dumping margins with and without zeroing. The order on diamond sawblades and stainless-steel plate in coils was revoked; both participating firms in stainless-steel sheet and strip in coils had their $\mathrm{AD}$ order revoked; however, because one Korean firm (Taihan) did not participate, margins for that firm were based on facts available and a duty remains in place.

While the US implemented the $\mathrm{AB}$ ruling, the fact that the US requested six months to recalculate the margins reflects its continued foot dragging with respect to zeroing decisions. We imagine that only a few minutes were needed for the USDOC to re-run its $\mathrm{AD}$ margins computer program with the zeroing code commented out. Yet, the US took months to implement. ${ }^{33}$

Moreover, the US already knew (at least) in November 2009 (when the consultations with Korea started) it would have to recalculate the margins. Yet, it refused to do so until months after the Panel made its perfunctory decision. This allowed it to levy zeroing-distorted margins for another 24 months after the consultations request.

29 US-Zeroing (Korea), para. 7.34.

30 Ibid., paras. 8.1-8.2.

31 US-Zeroing (Korea), WT/DS402/6, 22 June 2011.

32 US-Zeroing (Korea), WT/DS402/7, 9 December 2011.

33 The fact that Korea accepted and agreed to this time frame as 'reasonable' suggests that it could not do anything to force the US to implement more promptly. Nor, arguably, could the WTO DSU. Although obviously from a legal standpoint nothing prevents immediate implementation, the 'reasonable period of time' to implement DSU obligations is the recognition of the political and practical adjustment required by compliance. 
Table 3. OI weighted-average anti-dumping duty margins, with and without zeroing

\begin{tabular}{lll}
\hline \hline Exporter/manufacturer & $\begin{array}{l}\text { OI W. Avg. margin } \\
\text { (with zeroing) }\end{array}$ & $\begin{array}{l}\text { OI W. Avg. margin } \\
\text { (without zeroing) }\end{array}$ \\
\hline Diamond sawblades & & \\
$\quad$ Ehwa & 8.80 & 0 \\
$\quad$ Shinhan & 16.88 & 0 \\
$\quad$ Hyosung & 6.43 & 0 \\
$\quad$ All others & 11.10 & 0 \\
Stainless-steel plate in coils & & 0.55 (de minimis) \\
$\quad$ Pohang Iron and Steel & 6.08 & 0.55 (de minimis) \\
$\quad$ All others & 6.08 & 0 \\
Stainless-steel sheet and strip in coils & & 0 \\
$\quad$ Pohang Iron and Steel & 2.49 & 58.79 \\
$\quad$ Inchon Iron and Steel & 0 & (facts available) \\
Taihan Electric Wire & 58.79 & 19.60 \\
$\quad$ All others & (facts available) & \\
\hline \hline
\end{tabular}

Notes: ${ }^{1}$ Diamond Sawblades, from 71 Fed. Reg. 29310 (22 May 2006) and as amended 75 Fed. Reg. 14126 (24 March 2010); Stainless Steel Plate in Coils and Stainless Steel Sheet and Strip in Coils from 66 Fed. Reg. 45279 (28 August 2001).

${ }^{2}$ Diamond Sawblades, from 76 Fed. Reg. 66892 (28 October 2011); Stainless Steel Plate in Coils and Stainless Steel Sheet and Strip in Coils from 76 Fed. Reg. 74771 (1 December 2011).

\section{Analysis of Panel's decision}

Bown and Prusa document that between the first zeroing dispute of 1998 and early 2010 nearly 20 WTO disputes have involved zeroing. ${ }^{34}$ Consequently, there are numerous WTO AB rulings on the issue and also a considerable body of legal and economic analyses of zeroing. ${ }^{35}$

The key phrase is contained in Article 2.4.2 of the ADA:

the existence of margins of dumping during the investigation phase shall normally be established on the basis of a comparison of a weighted average normal value

34 Bown and Prusa, 'US Anti-Dumping', supra at note 3.

35 Including Janow and Staiger, 'European Communities - Anti-Dumping Duties on Imports of Cotton-Type Bed Linen from India'; Grossman and Sykes, 'European Communities - Anti-Dumping Duties on Imports of Cotton-Type Bed Linen from India'; Bown and Sykes, 'The Zeroing Issue'; Prusa and Vermulst, 'A One-Two Punch on Zeroing'; Prusa and Vermulst, 'United States - Continued Existence and Application of Zeroing Methodology'; Crowley and Howse, 'US-Stainless Steel (Mexico)'; and Hoekman and Wauters, 'US Compliance with WTO Rulings on Zeroing in Anti-Dumping' - see supra at note 10; Prusa and Vermulst, 'United States - Anti-Dumping Measures on Polyethylene Retail Carrier Bags from Thailand' - see supra at note 7 . 
with a weighted average of prices of all comparable export transactions or by a comparison of normal value and export prices on a transaction-to-transaction basis. ${ }^{36}$

The case does not add much to the existing WTO rulings on zeroing. We agree with Prusa and Vermulst who stated:

the Appellate Body was arguably correct in prohibiting the use of zeroing under the main methods of Article 2.4.2 of the $\mathrm{ADA}^{37}$

and with Prusa and Vermulst who wrote:

We agree with the legal justification logic behind the AB's decisions - given that this case largely follows the script developed in prior cases, this should not be surprising. Further, as we have argued in the past, we also believe that standard economic statistical inference methods demand that all transactions be included in a 'fair' comparison. ${ }^{38}$

With nothing new to add to the existing commentary on zeroing, we instead discuss several related issues in this case that raise broader questions with respect to the WTO DSU system and build on Prusa and Vermulst who commented on the very similar US-PET Bags (Thailand) decision.

\subsection{The real issue of undisputed claims}

Even though the US had not contested Korea's claim, the Panel nevertheless considered it necessary, in accordance with the approach of previous Panels, ${ }^{39}$ to satisfy itself - albeit in a summary fashion - that Korea had discharged its burden of proof, establishing a prima facie case. All this under Article 11 DSU, which requires the Panel to make 'an objective assessment of the matter before it, including an objective assessment of the facts of the case and the applicability of and conformity with the relevant covered agreements and make such other findings as will assist the DSB in making the recommendations or in giving the rulings provided for in the covered agreements'. ${ }^{40}$ It therefore followed the analysis we have outlined in Section 2 above.

The analysis covers some nine of the 17 pages of the Report, and most of it is taken up by quotations from previous $\mathrm{AB}$ and Panel Reports.

36 Article 2.4.2, Agreement on the Implementation of Article VI of the General Agreement on Tariffs and Trade 1994.

37 Prusa and Vermulst, 'A One-Two Punch on Zeroing', p. 188, supra at note 10.

38 Prusa and Vermulst, 'United States-Continued Existence and Application of Zeroing Methodology', pp. 46-47, supra at note 10.

39 US-Shrimp (Ecuador); US-Shrimp (Thailand). Compare David Palmeter and Petros C. Mavroidis (2004), Dispute Settlement in the World Trade Organization (second edn), Cambridge, UK: Cambridge University Press, p. 145.

40 US-Zeroing (Korea), para. 7.15. 
The Panel did ensure that a violation had occurred. This was made easy by the uncontested nature of the facts and the clear and undisputed illegality of the practice of zeroing. Indeed, the US's recognition of the breach already significantly contributed to making the establishment of Korea's prima facie case easier. In other words, the threshold is naturally lower for complainants faced with undisputed claims.

Thus, even though one could argue the necessity of analyzing an undisputed claim, what can in fact be challenged is the depth of the assessment of the breach. One could certainly envisage a more straightforward procedure, particularly in a paradigmatically simple dispute such as this one. Arguably, as the EU suggested, one step further could have been taken without any major breach of the rules of evidence. In consideration of the undisputed description of facts and of their legal assessment, the Panel might well have found that there was no dispute in the first place and move to its rulings and recommendations without much further ado. ${ }^{41}$

Whatever it may be, no serious analysis was required and indeed no significant clarification of the law made by the Panel. From an economic viewpoint, no significant amount of resources were used (or wasted) because of the Panel's analysis - but for time. And, in a context where compliance is taken to be only prospective (and normally commences only after the expiration of a 'reasonable period'), time does matter. ${ }^{42}$

In other words, the fact that the claim was both factually and legally undisputed raises other questions, going beyond the necessity for Panels to perform their (in such circumstances) pretty straightforward review. Why, despite the parties were in agreement with respect of the breach, was litigation necessary in the first place? Is it a desirable use of the WTO Dispute Settlement System? If not, what could be done to improve the situation?

\subsection{Implications of USDOC's insistence on adverse finding before recalculating margins, retrospective remedies, and continuing breach}

The USDOC announced it would cease zeroing in original investigations on 27 December 2006; the effective date of this final modification was 16 January 2007. Since that time, in each of the WTO disputes involving zeroing in OI (all commenced before the change in policy), the US has not contested the claims. Nevertheless, the US has insisted that the WTO DSB make a ruling in each case

41 US-Zeroing (Korea), para. 7.10.

42 Although the simplicity of the case certainly meant that the time requested for the proceedings was shorter than would otherwise have been. For example, after consulting the parties, the Panel decided not to hold a second substantive meeting with the parties. See para. 1.6 of the Panel Report. The Panel stage thus lasted eight months rather than the usual average of 14.7 months. See Henrik Horn, Louise Johannesson, and Petros C. Mavroidis (2011), 'The WTO Dispute Settlement System (1995-2010): Some Descriptive Statistics', 45:6 Journal of World Trade, 1107-1138. 
before it recalculates margins that were originally computed before the policy change.

From a political viewpoint, the continuous involvement of the US in zeroing cases can be explained in the following way. Domestic action, which is rational (assuming the compliance with international obligations contributes to the broad domestic-welfare outcome expected from them) but unpopular (because it decreases the welfare of well-defined and organized stakeholders), becomes possible if governments present it as an inescapable international commitment. As Mavroidis notes:

one cannot exclude the cases where recourse to dispute settlement is done on commitment grounds; the defendant prefers to lose and comply using the WTO as an excuse for behavior that it would not have otherwise adopted for domestic political economy reasons. ${ }^{43}$

With another language, to some extent the continuing litigation on zeroing - nearly 20 WTO Disputes, the sheer majority of which has the US as defendant - could be explained as an instrument for 'temporizing', as Hudec called it:

Thus, any device which helps to smooth the process by which the losers learn to accept their losses actually makes a valuable contribution to the cohesion, and thus the well-being, of the entire collective entity. It also keeps politicians in office, of course. ${ }^{44}$

For all practical purposes, however, the WTO Dispute Settlement Body is paying the price for the US's overly narrow implementation of the zeroing decisions. By way of comparison, in the aftermath of the EC-Bed Linen zeroing dispute, which also involved model zeroing, the EU offered interested parties affected by zeroing in other EU cases the opportunity to request a review. It also refrained from applying model zeroing after the adoption of the AB Report.

The US's approach has important economic consequences. The US implementation means that zeroing-inflated anti-dumping duties will continue to be assessed on many existing cases. According to Prusa and Vermulst, there are as many as 200 cases with zero-inflated anti-dumping duties that have not yet been recalculated. Of this set, perhaps 20 have sufficiently low margins to warrant bringing a WTO dispute. ${ }^{45}$ In effect, the US implementation shifts the cost of compliance on to its trading partners (via the costs required to pursue the dispute) and to the WTO DSB.

From a legal viewpoint, there are two orders of considerations: the first on remedies, the second on breach.

43 Petros C. Mavroidis (2012), 'A Little Bit Less Conversation and a Little More Action (Property and Liability Rules in the DSU Review of the WTO)', draft on file with the author.

44 Hudec, 'Transcending the Ostensible', p. 218, supra at note 1.

45 Prusa and Vermulst, 'United States - Anti-Dumping Measures on Polyethylene Retail Carrier Bags from Thailand', supra at note 7; and Bown and Prusa, 'US Anti-Dumping', supra at note 3, argue that only cases where removing zeroing will result in de minimis margins are suitable WTO disputes. 
First, as we have noted above, time plays in favor of the defendant in the WTO DSU. The US narrow approach to implementation to the repeated (eventually accepted) condemnation of zeroing methodology by the WTO DS underlies this case and mirrors the entrenched and (among Members) virtually universal view that WTO DS's rulings are for the future only and that remedies do not have any retrospective or retroactive effect. ${ }^{46}$

Although the suggestion that remedies could have some retrospective effect is highly controversial in the WTO ${ }^{47}$ in no less than five cases GATT Panel Reports in the field of anti-dumping and countervailing duties retroactive remedies were imposed. ${ }^{48}$ We agree with Mavroidis's assessment of the perverse disincentive a weak remedy has for illegally imposed anti-dumping duties:

what is the incentive for a WTO Member to respect the anti-dumping disciplines if it knows that, at worst, it risks seeing itself obliged to stop some four years down the road imposing duties that were illegally rendered in the first place? ${ }^{49}$

As noted by Prusa and Vermulst:

the prospective nature of WTO remedies limits their effectiveness, as the US zeroing saga abundantly shows. ${ }^{50}$

One certainly can question whether each and every case concerning anti-dumping duties based on zeroing methodology involves the issue of retrospectiveness. It may be argued that for certain administrative investigations that are not concluded - for example, when the duty or liability has only been provisionally

46 For an extensive discussion, see Petros C. Mavroidis (2000), 'Remedies in the WTO Legal System: Between a Rock and a Hard Place', 11:4 European Journal of International Law, 763-813; Piet Eeckhout (2009), 'Remedies and Compliance', in Daniel Bethlehem, Donald McRae, Rodney Neufeld, and Isabelle Van Damme (eds.), The Oxford Handbook of International Trade Law, Oxford, UK: Oxford University Press, pp. 437-459.

47 A good example is the reaction to the Panel Report in Australia-Subsidies Provided to Producers and Exporters of Automotive Leather-Recourse to Article 21.5 of the DSU by the United States, WT/ DS126/RW and Corr.1, adopted 11 February 2000, DSR 2000:III, 1189. See the DSB's discussion on the adoption of the Panel Report, WT/DSB/M/75.

48 The first case was New Zealand v. Finland (the Transformers case). On these GATT cases see ErnstUlrich Petersmann (1993), 'International Competition Rules for the GATT/WTO World Trade and Legal System', 27:6 Journal of World Trade, 35-86; Norio Komuro and Edwin Vermulst (1997), 'Anti-Dumping Disputes in the GATT/WTO: Navigating Dire Straits', 31:1 Journal of World Trade, 5-43. The political difficulties ensuing a finding that a retroactive repayment of illegally imposed duties can impose clearly come out from the Panel Report, Guatemala-Definitive Anti-Dumping Measures on Grey Portland Cement from Mexico, WT/DS156/R, adopted 17 November 2000, DSR 2000:XI, 5295, paras. 9.6-9.7. See Petros C. Mavroidis, Patrick A. Messerlin, and Jasper M. Wauters (2008), The Law and Economics of Contingent Protection in the WTO, Cheltenham, UK and Northampton, MA: Edward Elgar Publishing, pp. 258-260.

49 Mavroidis, 'A Little Bit Less Conversation and a Little More Action', supra at note 43.

50 Prusa and Vermulst, 'United States - Anti-Dumping Measures on Polyethylene Retail Carrier Bags from Thailand', supra at note 7 . 
determined - there is no need to talk of the retrospective effect, since the effect of the declaration of illegality would affect a pending situation.

Whatever it may be, it is reasonable to assume that, if WTO remedies have had some retrospective effects, the US would have more quickly changed its domestic laws so as to end this long zeroing litigation. ${ }^{51}$ Further, it looks intuitive that, if this remedial possibility would have been available and the US had not changed its policy, we would have had even more zeroing complaints against the US.

Secondly, it may be asked whether the narrow approach to implementation to WTO rulings finding the zeroing methodology illegal may constitute a case of breach 'having a continuing character'.

In public international law, this breach 'extends over the entire period during which the act continues and remains not in conformity with the international obligation'. ${ }^{52}$ As noted over and over above, the fact that US laws, by providing zeroing as the methodology to calculate dumping, were illegal under WTO has been repeatedly found by Panels and the Appellate Body. This was not contested but acknowledged by the US itself. It could therefore be argued that the breach of the relevant WTO laws has continued over time (by applying the same policy to the same and different investigations) and, for what matters to Korea, was still lasting in the anti-dumping investigations at issue in DS 402.

Bown and Sykes underlined the implications of the initial piecemeal approach of the WTO rulings on zeroing, comparing it with a more expansive approach that might have clarified the full scope of permissibility and impermissibility of zeroing across all of the procedures of the anti-dumping process in which it might be used. ${ }^{53}$ The deference of this approach can be understood. One of its negative implications, however, has been to blur the continuity of lack of compliance of US laws with WTO law. In more recent cases (US-Continued Zeroing (EC), ${ }^{54}$ US-Zeroing (Japan), ${ }^{55}$ and US-Zeroing (EC)), ${ }^{56}$ the complainants made very expansive claims against the practice. The WTO AB's decisions now imply that the practice of zeroing is inconsistent except under exceptional circumstances. ${ }^{57}$

51 See the negotiating proposal of Canada, TN/RL/GEN/37, which inter alia suggests that, in case of an anti-dumping or countervailing-duty measure found WTO law-inconsistent, the relevant Member 'should be obliged to apply the compliant measure to all past entries and, where application of the compliant measure yields lower duty liability, to refund all excess anti-dumping and/or countervailing duties collected pursuant to the original (WTO-inconsistent) measure'.

52 Article 14 of the International Law Commission's Articles on State Responsibility. See James Crawford (2002), The International Law Commission's Articles on State Responsibility Introduction, Text and Commentaries, Cambridge, UK: Cambridge University Press, pp. 135-140.

53 Bown and Sykes, 'The Zeroing Issue', supra at note 10.

54 United States - Continued Existence and Application of Zeroing Methodology, WT/DS350.

55 United States - Measures Relating to Zeroing and Sunset Reviews, WT/DS322.

56 United States - Laws, Regulations and Methodology for Calculating Dumping Margins ('Zeroing'), WT/DS 294.

57 This discussion is based on Bown and Prusa, 'US Anti-Dumping', supra at note 3. 
Although the practical implications of a ruling of continuing breach are not substantial, its clear and symbolic value and signal cannot be underestimated.

\subsection{The policy change of February 2012: all is well that ends well?}

Zeroing has also been an issue for duty calculations in periodic 'administrative reviews'. Under US AD law, the USDOC will, upon request, periodically conduct 'administrative reviews' of an $\mathrm{AD}$ order for purposes of (i) calculating the exact dumping margin for each exporter on entries covered by that review, and (ii) recalculating the duty deposit rate for future entries. Reviews are carried out indefinitely until the AD order is either completely or partially revoked. Typically, either domestic firms or foreign exporters will request a review within the first few years after the order was imposed.

The December 2006 policy change only affected zeroing in OI. The US only agreed to stop zeroing on administrative reviews in February 2012.58 The relevant timetable reads:

The Final Rule and Final Modification for Reviews will be effective and applicable to all reviews pending before the Department for which the preliminary results are issued after April 16, 2012. The Department will further apply the Final Rule and Final Modification of Reviews to all sunset reviews pending before the Department for which either the preliminary results or expedited final results of sunset review are issued after April 16, 2012. This methodology will be used in implementing the findings of the WTO panels in US-Zeroing (EC), US-Zeroing (Japan), US-Stainless Steel (Mexico), and US-Continued Zeroing (EC), with respect to any antidumping duty proceedings conducted pursuant to section 129 of the URAA. This methodology will also be applicable to any reviews currently discontinued by the Department if such reviews are continued after April 16, 2012 by reason of a final and conclusive judgment of a US Court.

This policy change should result in most countries simply requesting an administrative review rather than pursuing WTO litigation since a successful WTO ruling essentially just forces the US to perform a non-zeroing calculation. ${ }^{59}$

Since, however, as the zeroing saga shows, compliance with WTO rulings is often erratic, one cannot exclude the fact that Member governments will continue WTO litigation under Article 21.5 of the DSU claiming lack of full compliance as to refund of duties after the 'Reasonable Period' ended.

58 'Antidumping Proceedings: Calculation of the Weighted-Average Dumping Margin and Assessment Rate in Certain Antidumping Duty Proceedings; Final Modification', Federal Register, 77:30 (14 February 2012), pp. 8101-8114.

59 The only difference is that the margins are calculated for different periods of time. A recalculated OI margin would be based on a different (earlier) set of transactions than an administrative-review margin calculation. This timing difference is unlikely to generate a WTO dispute. 


\subsection{Unliquidated cash deposits: taking WTO DSU recommendations seriously}

The US is unique in that it uses a retrospective system to compute duties while most other WTO members use a prospective system. Bown and Prusa argue that the differences in the duty-assessment systems in the EC and US partly explain why they responded differently to the WTO rulings. ${ }^{60}$ In the prospective system, the dumping margin is established on the basis of the original investigation. In the retrospective system used by the United States, the dumping margin calculated in the initial investigation only establishes the deposit rate. The actual dumping margin is established during an administrative review.

An issue that emerged in the implementation phase was the appropriate way to handle cash deposits that had been collected (based on zeroing methodology) but had not yet been liquidated. The US will not implement with regard to what it considers a previous violation. The US believes it is sufficient to abandon zeroing on a forward-looking basis and that this implementation is enough to comply. The US's position is particularly problematic in this case.

For SSPC and SSSSC, there had been no shipments for many years and thus there were no deposits that could potentially be refunded. However, for diamond sawblades there were unliquidated cash deposits and these deposits could be potentially refunded. Recall that the US changed its policy regarding zeroing in OI in December 2006. Due to legal appeals, the cash-deposit order on sawblades began in January 2009, only after the US Court of International Trade remanded the USITC's negative injury determination. In other words, the US began to collect $\mathrm{AD}$ deposits over two years after it ceased zeroing in original investigations.

While unliquidated deposits were not in the scope of the dispute, Korea requested that the US refund the unliquidated deposits but the US refused. The instance of refusal to refund the unliquidated cash deposits is another clear example of the US's narrow approach to implementation of WTO zeroing decisions.

Certainly, a not-too-narrow reading of the standard recommendation to bring the measures (i.e., final determinations, amended final determinations, antidumping duty orders, and amended anti-dumping duty orders) in conformity with its obligations under the Anti-Dumping Agreement does involve the repayment of sums collected on the basis of those orders and of a calculation that has been found illegal. In other words, there are no reasons to disturb the principle of no ultra petita. The refund of sums collected on the basis of a methodology that has been expressly found to be illegal is a reasonable and direct consequence of the ruling of illegality.

60 Bown and Prusa, 'US Anti-Dumping', pp. 373-374, supra at note 3. This would depend on the fact that the retrospective system may amplify the effect of zeroing on dumping margins thus possibly explaining the US's resistance to implement WTO rulings. 
The US refusal to refund the unliquidated cash deposits may also represent a good example of the weakness of the WTO DSU at the remedy level, which has been noted above. If WTO remedies were retroactive, it can reasonably be argued that the US would not be able to refuse repayment. But, even without invoking the far-reaching and emotion-stirring notion of retroactivity, it could be argued that since, in the US retrospective system to compute duties, cash deposits are collected only on the basis of the provisional determination of the initial investigation and do not reflect the actual dumping margin (which is established only during an administrative review), the procedure would still be current and subject to review.

\section{Concluding comments: how strong is the law coming out from the WTO DSU?}

The Panel's decision in US-Zeroing (Korea) does not have significant legal or economic interest with respect to the issue of zeroing. In its decision, the Panel simply restated long-standing (and numerous) Appellate Body views on the inconsistency of zeroing with Article 2.4.2 of the ADA.

After at least 20 disputes and more than 13 years of WTO litigation which repeatedly confirmed the illegality of zeroing, it comes as welcome news that the US finally decided to also stop zeroing in administrative reviews. Hopefully, for the health of the WTO DSU, this long-simmering irritant has come to an end.

What starkly emerges from this zeroing-litigation saga is a more general consideration of the weakness in the WTO DSU system and of the ability of one country to take advantage of it. Important questions can be made. Why do countries litigate although the law is clear and the facts undisputed? How much stronger is domestic politics than international legal obligations? To what extent does the current WTO DSU system reflect or favor this state of affairs? And, more importantly, what could be done to prevent, in the future, long-lasting footdragging like that witnessed with the US and zeroing? Would broader findings that any continuity of the illegality be established make any difference? Would complainants ask for this, and would Panels and the Appellate Body promptly respond to the call? Further, would a change of view on the lack of retrospective effects of remedies in the WTO help? In public international law, we do have retrospective remedies since the Chorzow Factories decision of the International Court of Justice in 1929. Why is this so difficult in the WTO? Is it because the WTO DSU is lex specialis to the general rules of State responsibility? Or is there any other reason that makes countries reluctant to be subject to more robust remedies in the WTO? Although certainly politically sensitive, would a statement that duties calculated on the basis of zeroing should be recalculated and any sum levied repaid be so revolutionary? In a word - how binding and strong is the law coming out from a WTO dispute? And - crucially - how binding and strong do its Members want it to be? 